\title{
Importance of Early Intervention and Special Educational Support for High School Students with Attention-Deficit/Hyperactivity Disorder
}

\author{
Takuji Inagaki1*, Rei Wake ${ }^{2}$ \\ ${ }^{1}$ Faculty of Education, Shimane University, Matsue, Japan \\ ${ }^{2}$ Faculty of Medicine, Shimane University, Izumo, Japan \\ Email: ^inagaki@edu.shimane-u.ac.jp
}

How to cite this paper: Inagaki, T. and Wake, R. (2017) Importance of Early Intervention and Special Educational Support for High School Students with AttentionDeficit/Hyperactivity Disorder. Open Journal of Psychiatry, 7, 71-78.

https://doi.org/10.4236/ojpsych.2017.72007

Received: January 12, 2017

Accepted: April 15, 2017

Published: April 18, 2017

Copyright (๑) 2017 by authors and Scientific Research Publishing Inc. This work is licensed under the Creative Commons Attribution International License (CC BY 4.0).

http://creativecommons.org/licenses/by/4.0/ (c) (i) Open Access

\begin{abstract}
Aim: The present study aimed to investigate problems relating to education, past situations and treatments in high school students with attention-deficit/ hyperactivity disorder (ADHD) and to discuss appropriate considerations. Methods: Participants were 6 students who were diagnosed with ADHD according to Diagnostic and Statistical Manual of Mental Disorders IV, Text Revision (DSM-IV-TR) criteria. Results: In total, 6 cases of high-school students with ADHD showed dominantly inattention features. They had notably not been diagnosed with ADHD or received appropriate special support education until they were of high-school age, although they had clearly shown characteristic features of the disorder from childhood. As a result, they had decreased motivation to study and showed indolence, and suffered from low self-esteem. Conclusion: This case report suggests that early diagnosis of ADHD and early intervention with special support education are of great importance. To support these students, better educational and medical support systems are warranted.
\end{abstract}

\section{Keywords}

ADHD, High-School Students, Special Educational Support

\section{Introduction}

Although attention-deficit /hyperactivity disorder (ADHD) is widely recognized as a childhood disorder, for the majority of children, symptoms persist through adolescence and into adulthood. ADHD has significant negative effects on educational functioning and academic performance of children. High school students with ADHD frequently experience academic difficulties and have lower 
self-esteem than students without ADHD. Although they have had learning difficulties or behavioral problems in childhood, many of students with ADHD may have been previously undiagnosed. Therefore, for early recognition of the disorder and prevention of long-term negative outcomes, it is important to identify the factors in childhood that lead to the persistence of ADHD and associated impairment. It is also required that high-school students be provided with the academic supports and services that they require. Special support education is important to foster positive long-term outcomes and prevent the decrease in their self-esteem. The following is a report of 6 high-school students with ADHD who were not appropriately diagnosed and treated.

\section{Material and Method}

We consecutively experienced six high-school students who were diagnosed with ADHD according to Diagnostic and Statistical Manual of Mental Disorder IV. Text Revision (DSM-IV-TR) criteria (American Psychiatric Association 2000) [1] in the psychiatry unit of Shimane University Hospital from 2013 to 2015. These 6 cases were selected out of 22 high-school students who came to our psychiatry unit during same period. They were free of neurological and cardiovascular diseases, and chronic diseases such as cancer or diabetes mellitus. We used the ADHD-Rating Scale IV (ADHD-RS IV) to define inattentiveness, hyperactivity/impulsiveness, and combined diagnostic subtypes of ADHD [2]. We fully preserved their anonymity in the case description. We investigated their academic challenges, past situations and treatments, current symptoms, and capability for social adaptation and discussed appropriate considerations regarding support systems for their future.

\section{Cases Presentation}

Table 1 indicates the clinical characteristics of the students. Table 2 shows their clinical features and histories. Their main complaints were decline in academic performance and forgetfulness. Almost all of them experienced some degree of difficulty in school in the past. Of the total, 5 were male. In total, 5 cases out of the 6 students predominantly revealed inattentive behavior and 1 showed a mixed pattern (hyperactive and inattentiveness). The following is a brief description of the past histories and clinical characteristics of the 6 cases of students with ADHD.

Case 1: Problematic behaviors were not addressed in childhood, other than in learning composition. After attending high school, he showed tiredness, forgetfulness regarding homework, and gradually worsening academic performance. He had not received educational support in the past.

Case 2: Both hyperactivity behaviors and inattentiveness began in childhood. He also experienced difficulties of in learning math. He did not receive special educational support or appropriate medical care. He experienced bullying in childhood. Smartphone (internet) addiction and sleep rhythm disorder persist. 
Table 1. The clinical characteristics of the students with ADHD.

\begin{tabular}{|c|c|c|c|c|c|c|}
\hline Age & 18 years old male & 16 years old male & 16 years old male & 15 years old male & 18 years old male & 16 years old female \\
\hline Introducer & School counselor & Psychiatrist & $(-)$ & $(-)$ & $(-)$ & Pediatrician \\
\hline Full IQ & FIQ:80 (WAIS-III) & FSIQ:110 (WISC-IV) & FIQ:110 (WAIS-III) & FIQ:130 (WISC-III) & $(-)$ & FSIQ:90 (WISC-IV) \\
\hline $\begin{array}{c}\text { First } \\
\text { diagnosis } \\
\text { of ADHD }\end{array}$ & This time & This time & 2 years before & 7 years before & This time & 3 years before \\
\hline $\begin{array}{l}\text { Diagnosis by } \\
\text { DSM-IV-TR }\end{array}$ & Inattentive type & Inattentive type & Inattentive type & Combined type & Inattentive type & Inattentive type \\
\hline Prognosis & $\begin{array}{l}\text { Graduated from } \\
\text { high school }\end{array}$ & $\begin{array}{c}\text { Dropped out of } \\
\text { school } \rightarrow \text { Transferred } \\
\text { to another high school. }\end{array}$ & $\begin{array}{c}\text { Dropped out of } \\
\text { school } \rightarrow \text { Transferred } \\
\text { to another high school. }\end{array}$ & $\begin{array}{c}\text { Stayed in } \\
\text { same grade. }\end{array}$ & $\begin{array}{c}\text { Stayed in } \\
\text { same grade. }\end{array}$ & $\begin{array}{c}\text { Dropped out of } \\
\text { school } \rightarrow \text { Transferred } \\
\text { to another high } \\
\text { school. }\end{array}$ \\
\hline
\end{tabular}

Table 2. The clinical features and past histories of the students.

\begin{tabular}{|c|c|c|c|c|c|c|}
\hline Age & 18 years old male & 16 years old male & 16 years old male & 15 years old male & 18 years old male & 16 years old female \\
\hline $\begin{array}{c}\text { Chief } \\
\text { Complaints }\end{array}$ & $\begin{array}{c}\text { Decline of academic } \\
\text { impairment. } \\
\text { Forgetfulness. }\end{array}$ & $\begin{array}{c}\text { Decline of academic } \\
\text { impairment. } \\
\text { Forgetfulness. }\end{array}$ & $\begin{array}{l}\text { Second opinion } \\
\text { for diagnosis } \\
\text { as ADHD. }\end{array}$ & $\begin{array}{l}\text { Decline of } \\
\text { academic } \\
\text { impairment. }\end{array}$ & $\begin{array}{c}\text { Decline of } \\
\text { academic } \\
\text { impairment. } \\
\text { Forgetfulness. }\end{array}$ & $\begin{array}{l}\text { Decline of } \\
\text { academic } \\
\text { impairment. } \\
\text { Forgetfulness. }\end{array}$ \\
\hline Infant age & & $\begin{array}{l}\text { Restlessness. } \\
\text { Frequently losing. }\end{array}$ & & $\begin{array}{l}\text { Restlessness. } \\
\text { Impulsiveness. } \\
\text { Short temper. }\end{array}$ & & \\
\hline $\begin{array}{l}\text { Elementary } \\
\text { school age }\end{array}$ & $\begin{array}{c}\text { Difficulty } \\
\text { in composition. }\end{array}$ & $\begin{array}{l}\text { Difficulty in } \\
\text { concentration and } \\
\text { time keeping. } \\
\text { Restlessness. }\end{array}$ & & $\begin{array}{l}\text { Difficulty in } \\
\text { concentration. } \\
\text { Damage of } \\
\text { bullying, }\end{array}$ & A poor memory. & $\begin{array}{l}\text { Difficulty } \\
\text { in studying. }\end{array}$ \\
\hline $\begin{array}{l}\text { Junior high } \\
\text { school age }\end{array}$ & $\begin{array}{c}\text { Inattention. } \\
\text { Difficulty in math } \\
\text { and communication. }\end{array}$ & $\begin{array}{c}\text { Difficulty in putting } \\
\text { in order. } \\
\text { Short temper. }\end{array}$ & $\begin{array}{l}\text { Damage } \\
\text { of bullying. }\end{array}$ & $\begin{array}{c}\text { Decrease in } \\
\text { motivation } \\
\text { to study. }\end{array}$ & Clumsiness. & $\begin{array}{c}\text { Decrease in } \\
\text { motivation } \\
\text { to study. }\end{array}$ \\
\hline $\begin{array}{c}\text { High } \\
\text { school age }\end{array}$ & $\begin{array}{c}\text { Decrease in } \\
\text { motivation to study. } \\
\text { Difficulty } \\
\text { in putting away. }\end{array}$ & $\begin{array}{l}\text { Decline of academic } \\
\text { impairment. }\end{array}$ & $\begin{array}{l}\text { Nonattendance } \\
\text { to school. }\end{array}$ & $\begin{array}{l}\text { Nonattendance } \\
\text { to school. Short } \\
\text { temper. Violence. }\end{array}$ & $\begin{array}{l}\text { Nonattendance } \\
\text { to school. } \\
\text { Difficulty in } \\
\text { putting away. }\end{array}$ & $\begin{array}{l}\text { Nonattendance } \\
\text { to school. } \\
\text { Defiance to } \\
\text { the family. }\end{array}$ \\
\hline $\begin{array}{l}\text { Learning } \\
\text { disabilitiy }\end{array}$ & $\begin{array}{c}(+) \\
\text { Composition, math, } \\
\text { science and reading. }\end{array}$ & $\begin{array}{c}(+) \\
\text { Composition and } \\
\text { math. }\end{array}$ & $\begin{array}{c}(+) \\
\text { Math. }\end{array}$ & $(-)$ & $\begin{array}{c}(+) \\
\text { Fine work. }\end{array}$ & $\begin{array}{l}(+) \\
\text { Composition } \\
\text { and math. }\end{array}$ \\
\hline $\begin{array}{l}\text { Past special support } \\
\text { intervention }\end{array}$ & $(-)$ & $(-)$ & $(-)$ & $(-)$ & $(-)$ & $\begin{array}{c}\text { Special } \\
\text { support class. }\end{array}$ \\
\hline Bothered feelings & $\begin{array}{l}\text { Anguish for } \\
\text { his ability. }\end{array}$ & $\begin{array}{l}\text { Anguish for his } \\
\text { ability. Low } \\
\text { self-esteem. }\end{array}$ & $\begin{array}{c}\text { Discontent for } \\
\text { previous diagnosis. }\end{array}$ & $\begin{array}{l}\text { Anguish for his } \\
\text { ability. Low } \\
\text { self-esteem. }\end{array}$ & $\begin{array}{l}\text { Anxiety for the } \\
\text { future. Low } \\
\text { self-esteem. }\end{array}$ & $\begin{array}{l}\text { Unwilling } \\
\text { to go to school. }\end{array}$ \\
\hline Victim of bullying & $(-)$ & $(+)$ & $(+)$ & $(+)$ & $(-)$ & $(-)$ \\
\hline Comorbidity & $(-)$ & (+) Anxiety & (+) Anxiety & $\begin{array}{c}(+) \\
\text { Depressive mood }\end{array}$ & (+) Anxiety & $(-)$ \\
\hline Internet addiction & $(-)$ & (+) Mobile phone & $(-)$ & $(+)$ Mobile phone & $(+)$ Mobile phone & (+) Mobile phone \\
\hline Sleep disturbance & $(-)$ & $(+)$ & $(-)$ & $(+)$ & $(+)$ & $(+)$ \\
\hline
\end{tabular}


Case 3: He was diagnosed as ADHD at another psychiatric clinic before; however, he was not convinced of the validity of the diagnosis and discontinued psychiatric clinic sessions and drug therapy.

Case 4: Although he was diagnosed with ADHD and started treatment in childhood, he did not receive special educational support. As a result, treatment and clinic visits were discontinued. He experienced bullying in elementary school. Smartphone (internet) addiction and sleep rhythm disorder persist.

Case 5: He had shown forgetfulness from childhood, and experienced difficulties with organization and planning. He also showed little emotion when he told a lie. He had not received special educational support.

Case 6: She had difficulty in learning and showed poor study skills since elementary school. She experienced increased academic impairment, with lower grade-point averages, placement in lower-level classes, and failure in more courses. Medication and special educational support were provided when she reached junior-high school age, but did not continue. Smartphone (internet) addiction and sleep rhythm disorder persist. We advised all of them to make a schedule everyday and to keep their sleep rhythm.

\section{Discussion}

Characteristic features of the cases are as follows:

1) In total, 5 of the 6 cases (cases 1, 2, 3, 5 and 6) were diagnosed with ADHD with inattentiveness, and in Case 4, the diagnosis was mixed-type ADHD. Also, 4 cases (cases 1, 2, 3 and 5) were diagnosed for the first time at high-school age. The diagnosis was first given at our psychiatry unit. The other two cases had been previously diagnosed and received ADHD medication therapy.

2) Although some behavioral and academic problems had been observed since childhood in 5 of the cases, the students had not received appropriate educational and/or medical support. Only 1 case (case 6) received academic intervention such as modified assignments and slower-paced instruction in a special-support class. Also, 5 of the students (cases 1, 2, 3, 5 and 6) showed some degree of learning disability.

3) In total, 3 cases (cases 2, 3 and 4) had experienced bullying by classmates. Almost all of them had negative feelings about themselves and low self-esteems.

4) Comorbidities of depressive mood and/or anxiety appeared in 4 cases (cases 2, 3, 4 and 5). Furthermore, in 4 cases, the students suffered sleep disturbance (day and night rhythm reversal) with smartphone (internet) addiction (cases 2, 4,5 , and 6).

5) Clinical courses: The convalescence of Case 1 suggested graduation from high-school to university. Cases 2, 3, and 6 had many absences from school and, transferred to another high school. Cases 4 and 5 remained in the same grade.

ADHD is generally the most common neuropsychiatric and neurobehavioral disorder beginning in childhood. The symptoms of ADHD include inattention, hyperactivity, impulsivity, disorganization, and academic and behavioral difficulties [3] [4]. We reported 6 cases of high-school students with ADHD, predo- 
minantly of the inattentive type. One of the important problems from almost all of these cases were that they had not been diagnosed with ADHD and received appropriate special educational support until they were of high-school age, even though they had clearly developed the characteristic clinical features in childhood. Therefore, they had difficulty learning and experienced several behavioral and academic problems. As a result, they had decreased motivation to study and exhibited behavioral problems, felt distressed, and had low self-esteem.

The intensity of hyperactive behaviors in children may subside with age; however, the characteristics of inattentiveness, organizational dysfunction, and impulsivity often persist [5]. Numerous follow-up studies have confirmed the persistence of ADHD symptoms into adulthood [6]. However, the inattentivedominant type of ADHD is not as apparent in its clinical course compared with the hyperactive-dominant type. In this case report, 5 of the 6 cases were not found to have exhibited the characteristic symptoms in childhood.

The disorder often impairs behaviors essential for adaptive functioning, in the academic, social, and psychological realms. As a result, ADHD has a significant negative impact on scholastic functioning and academic performance. Some students with ADHD are unable to take notes during lectures and do a poor job planning and completing schoolwork and studying for exams, and thus the persistence of ADHD symptoms and associated disorders may be negatively correlated with the individual's satisfaction with school life.

As for comorbidities, cognitive and emotional problems are well documented in ADHD. ADHD is associated with reduced executive functioning (e.g., working memory, response inhibition, and organization). In addition, ADHD is often associated with poor emotional and mood regulation, and irritability. Therefore, people with ADHD may have interpersonal-communication problems, in addition to adjustment difficulties [5]. There are serious consequences of ADHD in childhood and adulthood in terms of functional outcomes, and it has been suggested that early recognition and intervention for ADHD and comorbid mental disorders is important for improving future outcomes [7] [8].

In adolescents, mood disorders and substance-use problems can complicate the clinical course of ADHD. Of the total, 2 cases presented in this report showed mood disturbance and/or anxiety. The severity of ADHD and comorbidity results in widely varying courses of treatment, and many students discontinue treatment in adolescence and adulthood [5].

Furthermore, the comorbidity of learning disorder (difficulty) (LD) can also complicate the clinical course of ADHD.A large proportion of patients were previously undiagnosed with respect to ADHD, although many of them had been recognized as having learning difficulties in childhood [7]. The comorbidity of LD and ADHD is relatively high with approximately $31 \%-45 \%$ of students with ADHD having LD as well [5] [9].

Therefore, appropriate support, such as special educational support, may be essential to ensure positive long-term outcomes. High schools are required to provide students who have a disability with appropriate academic adjustments 
and auxiliary aids and services in order to allow them equal participation in educational programs. Several academic accommodations are possible: additional time for exams, distraction-free examination rooms, deadline flexibility, notetaking services, tutoring, alternative formats for exams, and adaptive equipment and technology [10]. Many students should receive more than one type of academic intervention such as extra time for tests and modified assignments, slower-paced instruction, progress monitoring, and case management [11].

Brook et al. [3] examined 308 students aged 12 - 18 years who had been diagnosed with ADHD and $\mathrm{LD}$, and reported that $34 \%$ of them reported being severely stressed when going to school and sitting in class. Their complaints were: tiredness and excessive need for sleep, frequent quarrelling with their friends, feeling different from other classmates, and having low self-esteem. Their grades were low on average; $94 \%$ reported feeling despair regarding their own ability and academic achievement, and 53\% reported feeling that their teachers don't understand them or their difficulties. Their frustration increases their anxiety, depression, and mood instability, and hence negative social interactions, and there is an absence of strong relationships. As a result, they feel decreasing selfesteem, different from and inferior to their classmates [3]. Consequently, they may develop a mood disorder.

In terms of addiction, ADHD is clearly associated with unhealthy behaviors and outcomes, including smoking, illicit substance use, accidents and injuries, obesity, and even attempting suicide [5]. In some cases, students with ADHD may be at higher risk of adopting certain problematic behaviors such as internet addiction and alcohol-related problems than those without ADHD. In this report, 4 students showed internet addiction (smartphone addiction) with sleep rhythm disturbances. There have been few investigations of the association between inattentiveness in adolescents and smartphone use, but a relationship between playing computer games, internet addiction, and inattentiveness has been described. Zheng et al. [12] investigated the prevalence of inattentiveness among middle school students and found it to be considerable, and inattentiveness in adolescents was significantly associated with the amount of time spent on entertainment on the mobile phone each day and night. In this report, 3 students were found to have disturbed sleep (with the day and night rhythms reversed), probably resulting from internet addiction, including computer games.

Prognosis is very important. High school students with ADHD are also significantly more likely to be absent or tardy and are more than eight times more likely to drop out of school than their peers without ADHD [13]. They are significantly more likely to withdraw from a course [11]. They also experience difficulties completing school work and have significantly lower grades, score significantly lower on standardized tests, and experience higher rates of special education placement, grade retention, and school dropout compared to students without ADHD [11] [14]. These patients were associated with dropping out of school and having fewer years of education [7]. Of the primary manifestations of $\mathrm{ADHD}$, inattentiveness appears to be a key factor influencing achievement 
among students; this symptom is associated with decreased academic and social adjustment, poor study skills, and more depressive symptoms. These symptoms resulted in increasing likelihood of failing courses and ultimately dropping out of school. In this report, 3 of the students dropped out of school. Individuals with ADHD may suffer reduced self-esteem, perhaps secondary to peer rejection or academic or occupational difficulties [5].

Therefore, it is important to identify the factors in childhood that lead to the persistence of ADHD and associated impairment for early detection and prevention of long-term negative outcomes [4]. Consequently, special educational support for these students is very important. There is, however, little data regarding special educational services provided to high-school students with ADHD. Although some evidence supports academic interventions, including instructional modification, self-monitoring, and social-skills training, which may improve academic performance, unfortunately few studies have examined school services for high-school students with ADHD in detail [11]. Leslie et al. [15] found that 15 - 17-year-old with ADHD received fewer school-based services than 11 - 12-year-old students. Murray et al. [11] reported that school graduation rates were significantly lower at schools attended by those with ADHD compared to schools attended by those without ADHD.

In addition, some educational support programs are important to prepare them for adult life with suitable skills and occupation and, for increasing selfesteem. Notably, recent prospective data indicate that early childhood attention problems prospectively predict adolescent academic failure and work disability $[5]$.

\section{Conclusion}

In total, this case report suggests that the early diagnosis of ADHD and early intervention of special educational support are important. In order to support these students, better educational and medical support systems are warranted.

\section{Conflict of Interest}

The authors state that the there are no conflicts that relate to this research.

\section{References}

[1] American Psychiatric Association (2000) Diagnostic and Statistical Manual of Mental Disorder. 4th Edition, Text Revision, American Psychiatric Association, Washington DC.

[2] DuPaul, G.J., Power, T.J., Anastopoulos, A.D., et al. (1998) ADHD Rating Scale-IV: Checklist, Norms, and Clinical Intervention. Guilford Press, New York and London.

[3] Brook, U. and Boaz, M. (2005) Attention Deficit and Learning Disabilities (ADHD/ LD) among High School Pupils in Horon (Israel). Patient Education and Counseling, 58, 187-191. https://doi.org/10.1016/j.pec.2004.08.011

[4] Cheung, C.H.M., Rijdijk, F., McLoughlin, G., Faraone, S.V., Asherson, P. and Kuntsi, J. (2015) Childhood Predictors of Adolescent and Young Adult Outcome in 
ADHD. Journal of Psychiatric Research, 62, 92-100.

https://doi.org/10.1016/j.pec.2004.08.011

[5] Nigg, J. (2013) Attention-Deficit/Hyperactivity Disorder and Adverse Health Outcomes. Clinical Psychology Review, 33, 215-228.

[6] Barkley, R.A., Fisccher, M., Smallish, L. and Fletcher, K. (2002) The Persistence of Attention-Deficit/Hyperactivity Disorder into Young Adulthood as a Function of Reporting Source and Definition of Disorder. Journal of Abnormal Psychology, 111, 279-289. https://doi.org/10.1037/0021-843X.111.2.279

[7] Fredriksen, M., Dahl, A.A., Martinsen, E.W., Klungsoyr, O., Faraone, S.V. and Peleikis, D.E. (2014) Childhood and Persistent ADHD Symptoms Associated with Educational Failure and Long-Term Occupational Disability in Adult ADHD. ADHD Attention Deficit and Hyperactivity Disorders, 6, 87-99.

https://doi.org/10.1007/s12402-014-0126-1

[8] Jandl, M., Steyer, J. and Kaschka, W.P. (2012) Adolescent Attention Deficit Hyperactivity Disorder and Susceptibility to Psychosis in Adulthood: A Review of the Literature and a Phenomenological Case Report. Early Intervention in Psychiatry, 6, 11-20. https://doi.org/10.1111/j.1751-7893.2011.00293.x

[9] DuPaul, G.J., Gormley, M.J. and Larancy, S.D. (2013) Comorbidity of LD and ADHD: Implications of DSM-5 for Assessment and Treatment. Journal of Learning Disabilities, 46, 43-51. https://doi.org/10.1177/0022219412464351

[10] Nugent, K. and Smart, W. (2014) Attention-Deficit/Hyperactivity Disorder in Postsecondary Students. Neuropsychiatric Disease and Treatment, 10, 1781-1791.

[11] Murray, D.W., Molina, B.S.G., Glew, K., Houck, P., Greiner, A., Fong, D., Swanson, J., Arnold, L.E. and Lerner, M. (2014) Prevalence and Characteristics of School Services for High School Students with Attention-Deficit/Hyperactivity Disorder. School Mental Health, 6, 264-278. https://doi.org/10.1007/s12310-014-9128-6

[12] Zheng, F., Gao, P., He, M., Li, M., Wang, C., Zeng, Q., Zhou, Z., Yu, Z. and Zhang, L. (2014) Association between Mobile Phone Use and Inattention in 7102 Chinese Adolescents: A Population-Based Cross-Sectional Study. BMC Public Health, 14, 1022-1027. https://doi.org/10.1186/1471-2458-14-1022

[13] Kent, K.M., Pelham Jr., W.E., Molina, B.S., Sibley, M.H., Waschbusch, D.A., Yu, J., Gnagy, E.M., Biswas, A., Babinski, D.E. and Larch, K.M. (2011) The Academic Experience of Male High School Students with ADHD. Journal of Abnormal Child Psychology, 39, 451-462. https://doi.org/10.1007/s10802-010-9472-4

[14] Evans, S.W., Langberg, J.M., Egan, T. and Molitor, S.J. (2014) Middle and High School Based Interventions for Adolescents with ADHD. Child \& Adolescent Psychiatric Clinics of North America, 23, 699-715. https://doi.org/10.1016/j.chc.2014.05.004

[15] Leslie, L.K., Lambros, K.M., Aarons, G.A., Haine, R.A. and Hough, R.L. (2008) School-Based Services Use by Youth with ADHD in Public-Sector Settings. Journal of Emotional and Behavioral Disorders, 16, 163-177. https://doi.org/10.1177/1063426608314290 
Submit or recommend next manuscript to SCIRP and we will provide best service for you:

Accepting pre-submission inquiries through Email, Facebook, LinkedIn, Twitter, etc. A wide selection of journals (inclusive of 9 subjects, more than 200 journals)

Providing 24-hour high-quality service

User-friendly online submission system

Fair and swift peer-review system

Efficient typesetting and proofreading procedure

Display of the result of downloads and visits, as well as the number of cited articles Maximum dissemination of your research work

Submit your manuscript at: http://papersubmission.scirp.org/

Or contact ojpsych@scirp.org 